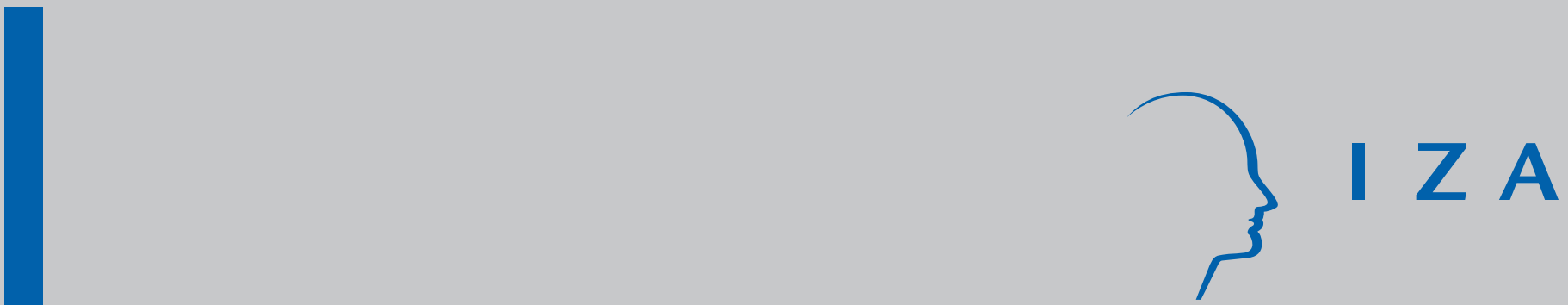

IZA DP No. 7281

Intrahousehold Bargaining and the Demand for

Consumer Durables in Brazil

Ana Claudia Polato e Fava

Mary Arends-Kuenning

March 2013 


\title{
Intrahousehold Bargaining and the Demand for Consumer Durables in Brazil
}

\author{
Ana Claudia Polato e Fava \\ CECS, Universidade Federal do $A B C$ \\ Mary Arends-Kuenning \\ University of Illinois at Urbana-Champaign \\ and IZA
}

Discussion Paper No. 7281

March 2013

\author{
IZA \\ P.O. Box 7240 \\ 53072 Bonn \\ Germany \\ Phone: +49-228-3894-0 \\ Fax: +49-228-3894-180 \\ E-mail: iza@iza.org
}

\begin{abstract}
Any opinions expressed here are those of the author(s) and not those of IZA. Research published in this series may include views on policy, but the institute itself takes no institutional policy positions. The IZA research network is committed to the IZA Guiding Principles of Research Integrity.

The Institute for the Study of Labor (IZA) in Bonn is a local and virtual international research center and a place of communication between science, politics and business. IZA is an independent nonprofit organization supported by Deutsche Post Foundation. The center is associated with the University of Bonn and offers a stimulating research environment through its international network, workshops and conferences, data service, project support, research visits and doctoral program. IZA engages in (i) original and internationally competitive research in all fields of labor economics, (ii) development of policy concepts, and (iii) dissemination of research results and concepts to the interested public.
\end{abstract}

IZA Discussion Papers often represent preliminary work and are circulated to encourage discussion. Citation of such a paper should account for its provisional character. A revised version may be available directly from the author. 


\section{ABSTRACT}

\section{Intrahousehold Bargaining and the Demand for Consumer Durables in Brazil ${ }^{*}$}

In Brazil, wives do most of the household work. About sixty percent of them also work outside the household, working a total of about 10 hours more per week than men. Because of this unequal distribution of household work, husbands and wives might have different priorities regarding the purchase of durable goods. Although both husbands and wives enjoy entertainment durable goods, wives might have a relative preference for householdproduction durable goods such as washing machines over entertainment durable goods such as televisions. Using a Brazilian household consumption survey, we examine whether decisions about ownership of entertainment and production durable goods are the outcomes of a bargaining process between husbands and wives. We use several variables to measure bargaining power, including the ratio of women to men in a state. The results indicate that decisions about durable goods ownership are the outcomes of bargaining processes between husbands and wives with wives having a relative preference for householdproduction durable goods over entertainment durable goods compared to their husbands. Bargaining might explain why ownership of household production durable goods is relatively low in Brazil, despite their potential to save women's time.

JEL Classification: J16, J12

Keywords: consumer durables, Brazil, household production

Corresponding author:

Mary Arends-Kuenning

Department of Agricultural and Consumer Economics

University of Illinois at Urbana-Champaign

408 Mumford Hall, MC-710

1301 West Gregory Drive

Urbana, IL 61822

USA

E-mail: marends@illinois.edu

\footnotetext{
* The authors are thankful to the comments of Charles Nelson, Andrea Beller, Hilarie Lieb, Karine Moe, Urvi Neelakantan, Angela Lyons, Gale Summerfield, Wendy Baldwi as well as to Ross Hanig and the participants of IPAD workshop, Labor Lunch, Midwest Economic Associations Meetings, Illinois Economic Associations Meetings and Brazilian Econometric Society and seminar participants at CEDEPLAR-UFMG and at USP-ESALQ.
} 


\section{Introduction}

The introduction and widespread adoption of consumer durables has had profound impact on family life throughout the world. Durable goods used in home production such as refrigerators, stoves, and washing machines have made women's work less physically taxing and have freed up women's time. Other consumer durables such as television sets, satellite dishes, and music players provide entertainment for family members. Because women traditionally do most of the housework, they primarily benefit from the purchase of homeproduction durable goods. Therefore, husbands and wives may have different preferences about purchasing durable goods, with wives giving higher priority to home-production durable goods relative to entertainment durable goods compared to their husbands. For example, although both husbands and wives might enjoy watching TV, when deciding which durable good to purchase next, a husband might prefer a second television set, whereas a wife might prefer a washing machine. Households' decisions about consumer durable purchases might be the outcome of a bargaining process between wives and husbands.

In this study, we examine household decisions to purchase consumer durables in Brazil. Brazil provides an interesting context to study consumer durable consumption because its economy is growing rapidly, and new consumer credit institutions are developing to allow middle class and lower-middle class consumers to purchase durable goods ((Jornal Estado de Sāo Paulo, 2009), (UOL online, 2009)). Consumer durable consumption has received attention at the highest national policy levels. In 2009, the Federal government lowered taxes on the so-called "white appliances" (refrigerators, stoves, and washing machines). The goals of the policy were to encourage consumers to replace their old models with new, energy efficient models and to increase poor households' access to washing machines ${ }^{1}$. Understanding whether consumer durable consumption is the outcome of a bargaining process

\footnotetext{
${ }^{1}$ Decreto N. 6.996, de 30 de outubro de 2009, Governo Federal.
} 
might help the private sector to sell more durable goods and government policymakers to achieve their policy goals more efficiently.

In addition, increasing women's access to home-production durable goods in Brazil might increase women's wellbeing. In 2001, women aged 25 to 45 who worked outside the household in Brazil spent an average of 10 more hours a week working and doing housework combined than men do (Figure 1). Female labor force participation of women aged 25 to 45 was 67.5 percent (PNAD 2001). However, despite this high participation rate during women's prime childbearing and childrearing ages, ownership of consumer durables was low. For upper income households, this fact might reflect the availability of maid services to do housework, but poor households cannot afford maid services. Only half of the households who comprised the poorest 20 percent of the population owned a refrigerator, about the same percentage that owned a color TV. Only 9 percent of households in the poorest 20 percent owned a washing machine (POF 2002/2003). Increasing women's bargaining power might shift household consumption from entertainment consumer durables to household production consumer durables. To the extent that durables such as washing machines and refrigerators save time and promote a healthy home environment, women's wellbeing is increased by their purchase.

To examine whether consumer durable purchasing decisions are the outcome of a bargaining process between husbands and wives, we use two high-quality data sets from Brazil. The Pesquisa de Orçamento Familiares (POF) is a household expenditure survey that includes information about purchase of durable goods and about household inventories of durable goods. These data are used to construct two dependent variables - the ratio of the value of services from household-production durable goods to the value of services of entertainment durable goods and the ratio of the number of household-production durable goods to the number of entertainment durable goods. The expenditure survey data also include demographic characteristics, income measures, and indicators of which household 
members make purchasing decisions. These data are combined with information obtained from a national, annual household survey, thePesquisa Nacional Por Amostra de Domicílios (PNAD), which is used to construct measures of how favorable local labor markets are to women. Bargaining power of women is measured by local marriage market conditions, indicators of who makes household purchasing decisions, and educational and age differences between husbands and wives.

We find that bargaining power between husbands and wives affects consumer durable consumption in Brazil. As the bargaining power of women increases, households spend relatively more on household production durable goods compared to entertainment durable goods. Households in which women have higher bargaining power also own relatively more home production durable goods compared to households in which women have lower bargaining power.

\section{Consumer durables and women's work load}

One of the main concerns of Brazilian women is the unfair division of housework (Oliveira, 2000). Given their increasing participation in the job market and their inability to engage their husbands in housework, the result is a double burden(Oliveira, 2000). Historically, the double burden was eased in developed countries by the introduction of durable goods such as washing machines, dryers, and vacuum cleaners. Recent studies have concluded

that the widespread availability of home-production durable goods was instrumental to free women's time to work outside the household in the United States (Greenwood, Seshadri, and Yorukoglu, 2005) and in seventeen OECD countries (Cavalcanti and Tavares, 2008). For example,Cavalcanti and Tavares (2008) estimate that a decline in the relative price of household appliances accounted for 10 to 15 percent of the increase in the labor force participation of women in the United Kingdom from 1975 to 1999. 
Although some dispute the importance of durable goods for the expansion of women's labor force participation (Jones, Manuelli, and McGrattan, 2003), there is agreement that these goods improved household welfare. Owning durable goods such as washing machines promoted cleanliness by allowing women to clean clothes and houses more often (Jones, Manuelli, and McGrattan, 2003). Between 1900 and 1970, the introduction of home-production durable goods reduced the time spent doing housework by 70 percent and resulted in a large decrease in the number of maids employed by U.S. households (Greenwood, Seshadri, and Yorukoglu, 2005).

In Brazil, low ownership of consumer durables adds to women's burden, especially among the low-income households. Wealthy households rely on maids to do housework, with 30 percent of the wealthiest 20 percent of households employing maid services (Table 2). Among the 20 percent poorest households, less than 1 percent employ a maid, and only 9 percent own a washing machine. Washing clothes by hand is time consuming, physically taxing work. At the same time, 47 percent of the poorest households own color television sets. Perhaps men and women both value entertainment durable goods over household-production durable goods. However, it is worthwhile to explore whether these decisions are the outcomes of a bargaining process to find out whether women would prefer to buy household-production durable goods if they had the power to decide.

\section{A model of intrahousehold bargaining over consumer durables}

We assume that husbands and wives bargain over whether to buy entertainment durable goods or home-production durable goods. Compared to husbands, wives have a stronger preference for home-production durable goods relative to entertainment durable goods. We do not give a specific intrahousehold bargaining model because the model could be 
either cooperative, such as the Nash bargaining model (Thomas, 1990, 1997; Manser and Brown, 1980; McElroy and Horney, 1981) or non-cooperative, such as the separate spheres bargaining model in Lundberg and Pollak (1993). Whether the model is cooperative or non-cooperative, household consumption decisions are affected by spouses' threat points, or utility outside of the marriage. The higher a spouse's threat point, the stronger the spouse's bargaining power, and the more likely that household behavior will reflect that spouse's preferences. We combine a bargaining model with the household production model in Becker (1965).

Within the household, husbands and wives obtain utility from their consumption of goods, household commodities, and leisure.

$$
U^{h}=U^{h}\left(x_{h}, l_{h}, z_{h}\right) ; U^{w}=U^{w}\left(x_{w}, l_{w}, z_{w}\right)
$$

Where $h$ refers to the husband, $w$ to the wife, $x$ to goods and services bought in the market, $l$ to leisure, and $z$ to home-produced commodities such as meals and home cleanliness.

The household produces commodities such as meals by combining purchased inputs such as groceries with household members' time.

$$
z_{h, w}=f\left(x_{z}, t_{z h}, t_{z w}\right)
$$

Where $x_{z}$ is an input into commodity $z$, and $t$ represents the time input of husbands and wives. The production function for commodities is flexible, so that they can be produced with different combinations of household members' time, purchased time from maids, and home-production durable goods. For example, households might produce a commodity such as clean clothes by combining 5 hours of the wife's time with water, a sink, and a clothesline, or by combining 30 minutes of the wife's time with the use of a washer and dryer. 
The home production decision is determined by the husband's and wife's utility function, the bargaining model, the home production function, and the full-income budget constraint:

$$
p_{h} x_{h}+p_{w} x_{w}+p_{z} x_{z}=w_{h} t_{m h}+w_{w} t_{m w}+I_{h}+I_{w}
$$

Where $p$ is the price of the husband's and wife's goods, $p_{z}$ is the price of the goods that are inputs into home production, $w$ is the market wage, $t_{m}$ is the time spent by the husband and the wife in the market, and $I$ represents unearned income. The production decision has implications for the amount of leisure that household members enjoy. This is one reason why wives may have different preferences than husbands about whether household production is time intensive or production durable-good intensive.

Assume that durable goods, $x_{z}$, are inputs into commodities, $z$. For entertainment durable goods, households might combine tv sets with time to produce a commodity called "enjoying a tv show." For production durable goods, households combine a stove with purchased food to produce a home-cooked meal. Consumer durable decisions will be a function of prices, wages, and husbands' and wives' preferences.

To test for bargaining, we identify variables that would not affect household consumption decisions if the household followed a unitary model, but might affect household consumption if the household followed a bargaining model. ${ }^{2}$ The key variable is a measure of marriage market conditions, the ratio of the number of women in an age group within a state to the number of men in an age group in a state. The variable should not affect household decisions if households follow a unitary model and seek to produce efficiently.

\footnotetext{
${ }^{2}$ In the literature, spouses' unearned income is commonly used as a measure of bargaining power. However, in Brazil, couples married before the 1980s face laws mandating that all assets are split. Starting in the 1980s, couples could choose at the time of the wedding how they would split their assets in the case of divorce. Therefore, current unearned income does not indicate the spouses' income in the case of divorce and is not an accurate measure of bargaining power.
} 
However, if a bargaining model describes household decisions, in states where the ratio of women to men is high, women would have a lower threat point and less bargaining power. We expect to find that households spend relatively more money on household-production durable goods when marriage market conditions favor women.

The other variables that measure bargaining power are indicators of whether household consumption decisions are made by the husband, the wife, or both, the difference between

the husband's age and the wife's age, and indicators of whether the wife has more than, less than, or equal education to the husband. We hypothesize that households spend relatively more on home-production durable goods when the wife makes the decisions and relatively more on entertainment durable goods when the husband makes the decisions. As the age between husband and wife increases, the wife has less bargaining power, and the household spends relatively more on entertainment durable goods. Finally, in households where the wife has more education than the husband, she has higher bargaining power, and the household spends relatively more on home-production durable goods.

\section{Data}

To test whether households make consumer durable purchasing decisions based on a bargaining model, we combine a Brazilian household survey, the Pesquisa Nacional Por Amostra de Domicílios (PNAD) with a Brazilian household expenditure survey, the Pesquisa de Orçamento Familiares (POF). The PNAD data offer detailed information about labor force participation and some information about hours spent on household work. In addition, PNAD is a large survey that covers almost all the counties in Brazil. We aggregated the PNAD data into state- and region-level variables that can be added to the household expenditure data. These aggregated variables include average income in the state, proportion of women who work in a birth cohort in a state, and average price of an hour of maid's 
services in the state. The marriage market variable is constructed by taking the ratio of women to men by birth cohort within a state.

Household expenditure data are available in the POF, which is similar to the U.S. Consumer Expenditure Survey (CEX). The 2002/03 POF contains detailed data about expenditure, income, and ownership of durable goods and is nationally representative. Durable goods expenditure and ownership data are available at the household level only. Therefore, it is not possible to determine individuals' consumption of these goods and the services that they provide.

The sample consists of 19,662 households in which both husband and wife are present and both are aged between 20 and 50 years old. Families are self-identified as a group of individuals who make common consumption decisions and share income. Descriptive statistics are reported in Table 1. The average household per capita monthly income is $R \$ 418$ (US\$139). Most households are composed of one family, but a few households consist of 2 or 3 families sharing a house. The average household size is 4 members. Husbands are on average 3 years older than wives. Women in Brazil obtained more schooling than men did, on average. Wives had at least one more year of schooling than their husbands in 42 percent of the households; husbands had at least one more year of schooling than their wives in 31 percent of the households; and in 27 percent of the households, spouses had the same schooling. However, an examination of the proportions of husbands and wives with various levels of education indicates that the distributions of men's and women's education are similar.

At the time households were interviewed for the POF, adults were asked whether they made expenditure decisions in order to determine their eligibility to participate in the personal expenditure survey. The information, although limited, can be used to construct variables indicating whether only the wife or only the husband reported making expenditure decisions. In 82 percent of the households, both spouses made expenditure decisions. Only 
16 percent of households reported that only the husband made expenditure decisions, and only 2 percent of the households reported that only the wife made expenditure decisions. In Brazil, it is the norm that husbands and wives both decide about household expenditure.

The data include detailed information about consumer durable purchases during the previous 12 months, in addition to an inventory of durable goods owned by the household. Household-production durable goods are defined as goods that save time in household production and include the following: stove/oven, refrigerator, washing machine, dryer, microwave, freezer, vacuum cleaner, and dishwasher. The entertainment durable goods include the following: color TV, black-and-white TV, radio, sound system, VCR, CD player, DVD player, computer, and satellite dish. On average, households own 8 percent more, and spend 29 percent more, on household-production durable goods compared to entertainment durable goods.

The three durable goods that are most often owned by households are stove/oven, color TV, and refrigerator (Table 2). Almost all of the richest 20 percent of households in the sample own these three goods. However, only 80 percent of the poorest 5 percent of households own a stove/oven. This percentage increases to 88 percent for the poorest 20 percent of households. About half of the poorest 20 percent of households own a color TV or a refrigerator, and only about 40 percent of the poorest 5 percent own a refrigerator. Among the poorest households, the fourth, fifth, and sixth most frequently owned durable goods are all entertainment durable goods-radios, black-and-white TVs, and satellite dishes. Fewer than 10 percent of the poorest 20 percent of households own a washing machine, and all other home-production durable goods are owned by less than 4 percent of these households. The rich households show preferences for washing machines, which are the fourth most frequently owned durable goods, followed by VCRs, computers, and microwaves. Poor households appear to spend their scarce resources on entertainment durable goods rather than home-production durable goods, with implications for women's domestic work burden. 
Household decisions about durable goods are certainly affected by their prices and the relationship between prices and household income. The ratios of the average prices of new durable goods to average monthly expenditure for each income quintile are presented in Table 3. The prices of home-production durable goods can also be compared to the prices of entertainment durable goods. For example, a color TV is expensive, costing about twice as much as the average expenditure of a household in the poorest quintile. A washing machine costs 1.5 times the average expenditure of these households, yet fewer households own this good. The most expensive goods are PCs, freezers, refrigerators, color TVs, DVD players, sound systems, washing machines, dishwashers, and CD players. The cheapest goods are radios, vacuum cleaners, black-and-white TVs, dryers, and stove/ovens.

\section{Defining the Dependent variable}

With the aim of exploring the relative preferences of husbands and wives for production and entertainment durable goods, two dependent variables are constructed from the POF data set-the expenditure ratio and the quantity ratio of household production to entertainment durable goods. The problem in working with durable goods is that consumption occurs over a long period of time. The purchase of a durable good can be seen as an investment made at a certain point in time, for which the return is the stream of services provided by the durable good during its lifetime. Individuals derive utility from the services that these goods provide.

Moreover, durable goods purchases are infrequent, and the survey follows households' purchases of durable goods for only one year. To deal with these difficulties, two different measures of relative allocation are constructed: the expenditure ratio and the quantity ratio.

We calculate the expenditure ratio of durable goods, defined as share $_{p / e}$, by calculating the monthly rental value of each durable good owned by the household and then aggregating 
the rental values into totals for production durable goods and entertainment durable goods. These rental values are estimated using a depreciation decay model, as discussed in Deaton and Zaidi (2002). The share is defined as the ratio of the sum of the rental values of production durable goods divided by the sum of the rental values of the entertainment durable goods. Details about the estimation procedure may be found in Appendix A.

The expenditure ratio takes on values that range from 0 to 39.52. As the value of share $_{p / e}$ increases, the household favors production durable goods over entertainment durable goods. This measure accounts for both the quantity and quality of the durable goods that the household consumes. If the household owns no entertainment durable goods, the variable is defined as the sum of the rental values for the production durable goods. This situation is rare, however. Only four percent of the households owned production durable goods, but no entertainment durable goods. And only three percent of the households owned entertainment durable goods, but no production durable goods.

The second dependent variable is the quantity ratio of durable goods, which is defined as the total number of production durable goods owned by the household divided by the total number of entertainment durable goods owned by the household. There are eight different types of production durable goods and nine types of entertainment durable goods. However, one household may have more than one unit of a specific durable good (e.g. two color TVs). We add up all the units of production and entertainment durable goods. This way, the quantity of production durable goods can be higher than eight and the quantity of entertainment durable goods can be higher than nine.

This relative allocation of production to entertainment durable good, $o w n_{p / e}$, is distributed as follows: 
(4) own $_{p / e}=\left\{\begin{array}{l}y=0: \text { no production and at least one entertainment good } \\ 0 \leq y<1 \text { : more entertainment than production goods } \\ y=1: \text { same amount of production and entertainment goods } \\ 1<y \leq P D G: \text { more production than entertainment goods }\end{array}\right.$

As in the share $_{p / e}$, household is assumed to have $o w n_{p / e}=P D G$ if it has at least one production good and no entertainment good and $o w n_{p / e}=0$ if a household owns no production good but owns at least one entertainment good. This variable orders the relative ownership of durable goods from relatively less to relatively more production goods. Notice that a household that owns a refrigerator and a TV is similar to a household that owns all of the production and entertainment durable goods. Notice, as well, that the distribution of the quantity ratio is censored at zero.

\section{State-Level Variables}

One of the measures of bargaining power between husbands and wives is the marriage market variable. We assume that the wife and the husband can leave the existing marriage and remarry. Therefore, the marriage market variable is constructed as the ratio of women to men in a given cohort and State of residence in 2001. Following the discussion in Fossett and Kiecolt (1991), we determined the appropriate definition of a marriage market in the Brazilian setting. The State is the smallest geographic unit that can be identified in the POF and PNAD, so marriage markets are defined at the state level. We examined marriage patterns by age (Appendix Table A.3), which indicated that men and women married within the same age cohort. For most of the men's cohorts, the wives' average age is close to the average age in that cohort, but when the wives' age is lower than the husbands' cohort age, that difference is well within the standard deviation, about 5.5 years. 
Therefore, the marriage market ratios are defined within the same cohort, for example, the ratio of 20- to- 24- year-old women to 20- to- 24- year-old men. Alternatively, the marriage market variable is defined where wives are assumed to belong to a younger cohort than husbands.

The marriage market variable is negatively associated with women's bargaining power. Therefore, if women prefer time-saving in household production durable goods over entertainment durable goods, the marriage market variable should have a negative effect on the dependent variable.

Other State-level variables are constructed using PNAD 2001, including the state average income, the proportion of working women by cohort and the average price of maid's services. Information about the expenditure of durable goods from the POF data set is used to calculate the prices of the services of durable goods, that is, the average rental value of production and entertainment goods by regions ${ }^{3}$. The averages were weighted by the households' ownership of these durable goods in the region. The price of electricity is the average price for 2002 and 2003 from the Agência Nacional de Enegia Elétrica (ANEEL). These variables are used in the regressions to capture other factors that differ across States and affect durable goods allocation such as differences in living standards, price differences and women's labor market participation. Because the marriage market variable is a state-level variable and States in Brazil differ regarding development stage and wealth, the regression must have these control variables to capture these differences. Otherwise, the marriage market variable would be capturing these differences as well.

\footnotetext{
${ }^{3}$ Because of the small number of observations on the purchase of certain durable goods in some states, especially the goods that have been recently introduced, the rental value was calculated by regions of Brazil.
} 


\section{$5 \quad$ Econometric Model}

To estimate the impact of bargaining power on the household's consumption of householdproduction durable goods relative to entertainment durable goods, we follow the econometric approach of Lundberg, Pollak, and Wales (1997). They used the expenditure ratio of children's goods to men's goods to examine the impact of changes in women's bargaining power on household consumption. Using ratios as the dependent variables allows us to estimate a single equation and to address potential bias due to measurement error. If the bargaining power variables have measurement errors, then their impact will bias the coefficient in the same direction in both equations. By estimating the ratio of the dependent variables, this bias will cancel out.

However, the specification is not a conventional demand analysis because the dependent variable is not a measure of purchase (flow) but instead is proportional to the stock of durable goods owned by the household. As pointed out by Deaton and Muellbauer (1980), in a cross-section analysis, the stock of durable goods is a better measure than purchases of individual durable goods because the relevant outcome is the choice between the ownership and nonownership of a durable good.

The equation that we estimate is as follows:

$$
\begin{aligned}
Y & =\gamma M M_{c s}+\beta_{w} D E_{w}+\beta_{h} D E_{h}+\theta_{1} D+\theta_{2} \bar{I}_{s}+\theta_{3} W W_{c s} \\
& +\alpha_{1} P_{\text {maid }}^{s}+\alpha_{2} P_{\text {prod }}^{s}+\alpha_{3} P_{\text {ent }}^{s}+\alpha_{4} P_{\text {elect }}^{s}+\alpha_{5} M
\end{aligned}
$$

As discussed above, the two dependent variables are share $_{p / e}$ and $o w n_{p / e}=P D G$. Several variables are proxies for bargaining power. The marriage market variable, $M M_{c s}$, is defined as the ratio of women to men in a given cohort c and State s. If household consumption of durable goods is the outcome of a bargaining process, and women prefer production durable goods relative to entertainment durable goods, then $M M_{c s}$ will have a negative 
and statistically significant coefficient. The variables $D E_{w}$ and $D E_{h}$ are, respectively, indicators of households in which only the wife and households in which only the husband reports making decisions about purchases. The other variables that capture bargaining power are the difference between the husband's and the wife's age and indicators of whether the wife has more schooling, less schooling, or equal amounts of schooling compared to the husband ${ }^{4}$. Variables that increase as the wife's bargaining power increases will have positive and significant coefficients.

Because the marriage market variable may be correlated with other cohort and State characteristics, we include a set of State- and regional-level ${ }^{5}$ variables as controls. These control variables are the average income in State s, Is, the proportion of working women in cohort $c$ and State $s, W W_{c s}$, the prices of maid's services, $P_{\text {maid }}^{s}$, prices of production, $P_{\text {prod }}^{s}$, and entertainment, $P_{e n t}^{s}$, durable goods and price of electricity, $P_{\text {elect }}^{s}$.

Finally, a set of household variables are used including the per capita income of the household, $M$, and a set of demographic variables, $D$, such as the number of people in the household (broken down by gender and age), the number of families in the household, the wife's age, and a set of dummy variables for wife's primary education, middle school, high school, and at least some college. In all regressions, standards errors are corrected by clustering based on state.

\footnotetext{
${ }^{4}$ We choose to use an indicator of whether the husband has more schooling than the wife instead of a specification that allows for a linear impact of the schooling difference between husbands and wives because little variation exists between husbands' and wives' schooling. The percentage of couples with equal years of schooling is 26 percent, and in 31 percent of the couples, the husband or the wife has one or two more years of schooling than his or her partner. Only in 17 percent of the couples does the husband have three or more years of schooling than the wife.

${ }^{5}$ The prices of electricity, production and entertainment goods are not available at State level, but they are at regional level.
} 


\section{Price and Income Effects}

Because the dependent variable is a ratio, and both the numerator and denominator depend on prices and income, the effects of prices and income are not straightforward to interpret by looking only at the coefficients of these prices and income variables. To overcome this problem, the response of the dependent variable to prices and income is derived. In most cases, the coefficients of these prices and income variables are proportional to the difference of the elasticity of production and elasticity of entertainment with respect to the specific variable. In Appendix B, the derivations of the price and income elasticities are presented.

\section{Results}

The main results are presented in Table 4 and Table 5, where in Table 4 the dependent variable is the expenditure ratio of production to entertainment durable goods, share $e_{p / e}$, and the dependent variable in Table 5 is the ratio of the quantity of production to entertainment durable goods, owns $p / e$. In column one, the results are the outcome of OLS estimation and, in column two, the Tobit estimation is used to deal with censoring of the dependent variable at zero. The results are quite similar between OLS and Tobit estimation with changes in the significance of few demographic variables.

The results from both tables are grouped into bargaining variables, demographic variables such as wife and husband's characteristics, and household variables, followed by the interpretation of the income and price coefficients. The section continues with a discussion of alternative measures of the marriage market variable, presented in Table 6 . The final subsection presents a discussion of the different impacts of the bargaining power variables across income groups, presented in Table 7. 


\section{Bargaining Power Variables}

In both tables 4 and 5, the marriage market variable indicates that the allocation of production and entertainment goods is an outcome of a bargaining process between husband and wife, that is, this variable is significant at $1 \%$. In a common preference decision process, this variable would not be significant because it does not affect preferences or household production decisions, but under a bargaining process this variable is significant because it affects the allocation through the threat point ${ }^{6}$. Moreover, the negative impact of the marriage market variable indicates that cohorts and States where an excess of women exists, lowering a wife's bargaining power, have lower expenditure on production relative to entertainment durable goods. This result confirms that wives prefer production to entertainment goods and husbands prefer entertainment to production goods.

The indicators of households in which only the wife and only the husband makes expenditure decisions imply that these households have higher allocation of production relative to entertainment goods than households in which both spouses report making expenditure decisions. This is true whether we examine shares of expenditure, or shares of the number of durable goods owned. That is, the coefficients of these two indicators are positively significant in tables 4 and 5. These results are consistent with the presence of a bargaining process between husbands and wives over production and entertainment goods in households in which husbands and wives make expenditure decisions. If households follow a non-cooperative bargaining model, the outcome may not be Pareto efficient, leading to a

\footnotetext{
${ }^{6}$ Even after controlling for State average income and proportion of working women in a given cohort and State, one may still wonder if the marriage market variable is capturing the bargaining power of wives or some other state effect. In reality, the correlation of the marriage market and the state income was around -0.12 and the correlation of the marriage market and the proportion of working women was around 0.07. Moreover, the test of variance inflation was rejected for all variables in the regression. These results indicate that the marriage market variable is capturing females' bargaining power for a given cohort in a given State.
} 
undersupply of public goods and services. However, when only one spouse makes the expenditure decision, the household is considered a unitary household. Household allocation is efficient because by assumption, unitary household models always result in an efficient allocation.

Compared to households in which the husband and the wife have the same level of education, households in which the wife has more schooling than the husband have higher allocation to household-production goods than to entertainment goods. While this impact is highly significant for relative expenditure, Table 4 , it is not significant for the relative quantity of production and entertainment goods, Table 5. Indeed, households in which the wife has at least one more year of schooling than the husband have a ratio of spending on production goods relative to entertainment goods that is 0.13 greater than households in which husbands and wives have the same educational level. On the other hand, households in which the husband has more schooling than the wife have the same allocation of production to entertainment goods compared to households in which spouses have the same education level.

To summarize, the results of the tests provided by the marriage market variable, the indicators of households in which only the husband or only the wife makes expenditure decisions and the differences in husbands' and wives' schooling rejects the common preference model in favor of a bargaining model. Moreover, there is evidence that wives prefer household-production durable goods and husbands prefer entertainment durable goods.

\section{Demographic Variables}

Wife's age and the difference between the husband's and the wife's age do not affect relative expenditure, Table 4, but they affect the relative quantity of production to entertainment goods, Table 5, lowering the quantity of production to entertainment goods. That is, as the wife gets older the number of entertainment goods relative to the number of production 
goods increases by $0.35 \%$; and for each additional year in the husband's age keeping the wife's age constant, the number of entertainment goods increases $0.2 \%$ more than the number of production goods. The fact that age and age difference do not affect the relative expenditure but affect the relative quantity is evidence that this increase in quantity of entertainment goods is due to the consumption of cheaper entertainment goods or more expensive production goods. Therefore the quantity of entertainment goods is larger, but the rental value is the same.

Households where the wife has incomplete secondary school or more have higher expenditure on entertainment relative to production durable goods compared to households where the wife has no education (Table 4). Households where the wife has some education, i.e. primary and incomplete secondary school, have more production relative to entertainment goods compared to those households where the wife has no education (Table 5). Except for households where the wife has high school, the relative number of production to entertainment goods is not significantly different from those households where the wife has no schooling. Moreover, households where the wife has college or more have a lower ratio of production to entertainment goods than households where the wife has no schooling. These results are consistent with a story that as the opportunity cost of the wives staying at home increases, they prefer to hire someone to replace their time in home-production, lowering their needs for production durable goods. There may be more scope for consumers to increase the quality and number of entertainment durable goods than the quality and number of home-production durable goods. For example, as households become wealthier, they can purchase televisions with larger and larger screens and with finer picture definition. By contrast, consumers probably care less about the top end of quality available in a washing machine.

The presence of children three years old and younger increases the expenditure on production relative to entertainment goods, as shown by the coefficients of number of 
daughter and sons three years and younger in Table 4. The presence of daughters four to six and thirteen to sixteen years old decreases the allocation of household-production to entertainment durable goods. The presence of sons seven to twelve years old decreases the relative quantity of production to entertainment goods (Table 5). The presence of women 61 to 70 years old decreases the relative quantity of production to entertainment goods (Table 5). This result is also consistent with a story of wives replacing their time in homeproduction with somebody else's time instead of using production durable goods, in this case wives' time is substituted by other women living in the household such as daughters or relatives. This kind of substitution occurs when a maid's time is not feasible or not viewed as a perfect substitute to a family member's time.

\section{Prices and Income Variables}

Household's per capita income has a negative and highly significant (1\%) impact on the allocation of production to entertainment durable goods (Tables 4 and 5). The impact of household's per capita income is consistent with a story that as the opportunity cost of the wives staying at home increases, they prefer to hire someone to replace their time in home-production, lowering their needs for production durable goods, supported as well by the wife's education impact.

The state's control variables, that is the proportion of working women by state and cohort and the average state income, are not significant. The coefficient of the price of maids is positively significant, around 0.4. Based on equations (B.1) and (B.6), production goods and maids are substitute factors in household production. For the country as a whole, the estimated cross-price elasticity of production goods and maids' services range from 0.5 to 0.64 depending on whether maids reside in the household of employment or not.

The effect of the price of production goods is positively significant, around 0.55 in 
Tables 4 and 5. Plugging the values presented on the descriptive statistic table on the right hand side of equation (B.2), it is found that $\varepsilon_{\text {production, } P_{\text {prod }}}-\varepsilon_{\text {entertainment, } P_{\text {prod }}}=2.9>$ 0. Assuming that production goods are neither Giffen nor Veblen goods, then own-price elasticity is negative. This implies that the cross-price elasticity of entertainment goods with respect to the price of production goods is negative, and therefore production and entertainment goods are complements. The same conclusions hold true if the results are analyzed using equation (B.7).

The effect of the price of entertainment goods is negatively significant, around 0.2 in Tables 4 and 5. Plugging the values presented in the descriptive statistic table into equation (B.3), it is found that $\varepsilon_{\text {production, } P_{\text {ent }}}-0.15 \varepsilon_{\text {entertainment, } P_{\text {ent }}}=0.55>0$. For the complementarity of the production and entertainment goods to hold, the entertainment goods must be more sensitive to changes in price of entertainment goods than production goods. The same conclusions hold true if the results are analyzed using equation (B.8). For the income effect, equations (B.5) and (B.10), together with the negatively significant monthly per capita income coefficient, around 0.09 in Table 4 and 0.03 in Table 5 , and the assumption that production and entertainment goods are not inferior goods, imply that entertainment goods are more sensitive to changes in income than production goods.

\section{Alternative Measures of Marriage Market}

In this study, the marriage market variable is the key variable used to test whether consumer durable consumption is the result of bargaining process. To check the robustness of the marriage market result, we explore other ways to define the Brazilian marriage market. The results are presented in Table 6. In general, the findings support the intrahousehold bargaining hypothesis and the hypothesis that women have a stronger preference for homeproduction goods than men do.

In the first and fourth columns of Table 6, the marriage market variable is defined 
assuming that men prefer to marry women in the next younger cohort. The estimated effects are smaller than when the marriage market was defined assuming that men and women were in the same age cohort (Tables 4 and 5). When the dependent variable is the ratio of the expenditures on durable goods, the marriage market variable is no longer statistically significant.

The other specifications in Table 6 define the marriage market based on the assumption that men and women prefer to marry spouses within their educational level as well as within their age cohort. The education groups used are defined as those having less than high school and those having at least some high school. The marriage market variable has a negatively significant effect assuming that husband and wife have the same educational level, and the husband's education is used to construct the marriage market variable (Columns 3 and 6, Table 6). The results flip to positive and insignificant when wife's

education is used to construct the marriage market variable (Columns 2 and 5, Table 6). When the results are significant, they indicate that the wife prefers household-production durable goods relative to entertainment durable goods.

\section{Results By Income Groups}

The regression results that we interpret as bargaining power effects might also be affected by interactions between income and the bargaining power variables. To examine this, the estimated coefficients of the bargaining power variables by income quintiles are presented in Tables 7 and 8 . The previous results included controls for per capita income, but this measure is an imperfect measure of permanent household income. Also, households may show heterogeneous consumer durable purchasing behavior depending on their income quintile.

The results in Tables 7 and 8 support the conclusion that consumer durable purchases are the outcome of bargaining processes, and that women have a stronger preference for 
production durable goods than men do. The coefficients on the marriage market variable remain negative and statistically significant across income groups, except for the lower and upper middle quintiles when the dependent variable is the expenditure ratio of production to entertainment good (Table 7). In these cases, the marriage market variable is not statistically significant. Consistent with the results presented in Table 4, looking at the expenditure ratio of production to entertainment good dependent variable (Table 7), households spend relatively more on production durable goods when only the husbands make decisions about expenditures, and this is consistent across income groups. When the dependent variable is the quantity of production to entertainment good (Table 8), households in the lower middle and high quintile show a significant positive effect of having only the husbands make expenditure decisions on ownership of home-production durable goods relative to entertainment durable goods.

We found previously in Table 5 that as the husband's age minus the wife's age increased, the relative ratio decreased, and we interpreted the result as showing that when husband's bargaining power increased, the household bought more entertainment durable goods relative to home-production durable goods. The results by income groups shows that this result is driven by behavior in the upper middle income quintile for the relative expenditure (Table 7) and in the high income quintile for relative quantity (Table 8). The difference between husband's and wife's age is negative and statistically significant in the upper middle income quintile for the relative expenditure (Table 7) and in the high income quintile for the relative quantity (Table 8).

The results for the husband's and the wife's education variables reveal interesting heterogeneity across income groups. The wife having more schooling than the husband is associated with higher relative expenditure (Table 7) on home-production durable goods only for the two highest income quintiles. Also for the two highest income quintiles, as wife's education increases, the relative expenditure on home-production durable goods de- 
creases. This is consistent with our earlier result and conclusion that entertainment durable goods have more scope for quality improvements than home-production durable goods.

When looking at the results when the dependent variable is the relative quantity in Table 8, households in which the wife has more education than the husband own fewer home-production durable goods relative to entertainment durable goods than households in which husbands and wives have equal educational levels. However, the result is only statistically significant for the lowest income group. This result is not consistent with a bargaining story where wives have stronger preferences for home-production durable goods than entertainment durable goods. Also, in the lowest income quintile, higher levels of wives' education are associated with more production goods relative to entertainment durable goods. The pattern is reversed for the highest income quintile, where higher levels of schooling are associated with lower ownership of home-production durable goods relative to entertainment durable goods. One story that is consistent with these heterogeneous results is that for women in low income quintiles, increased education (and the resulting higher opportunity costs) results in greater substitution of production durable goods for wives' time. However, for high-income quintiles, wives may choose to substitute maids' time for their time, and maids might be seen as substitutes for home-production durable goods.

\section{Conclusion}

This paper explores whether decisions about durable goods allocation are the outcome of a bargaining process between husbands and wives in Brazil. The variables that measure female bargaining power include a measure of the marriage market (i.e., the sex ratio), indicators of households in which only the husband and households in which only the wife makes expenditure decisions, the age difference between husbands and wives, and indicators of which spouse has more schooling. If husbands and wives share common preferences 
about durable goods allocation, then the relative allocation of household-production and entertainment durable goods will not be correlated with any of these bargaining power variables.

The results indicate that the decision about durable goods ownership is the outcome of a bargaining process between husband and wife. The test on the coefficients of the marriage market variable and the indicators of households in which only the wife and households in which only the husband make expenditure decisions corroborate the expectations about wives' preferences for production goods. Households in which the wife has more education than the husband also spend more on home-production durable goods relative to entertainment durable goods. However, results by income quintiles reveal that this effect of educational differences is found in the upper income quintiles and not in the lower income quintiles.

These results increase the understanding of consumer durable purchasing behavior in Brazil, identifying the reasons for the lack of household-production durable goods in Brazilian households and for the priority given to entertainment durable goods. Because husbands and wives bargain over decisions about durable goods ownership, wives have a stronger relative preference for production durable goods than husbands do, and husbands have higher bargaining power, ownership of production durable goods might be lower than what would be optimally chosen by women. Under these circumstances, it is not surprising that a 2009 Brazilian policy designed to stimulate the sales of "white appliances", combined with an expansion of stores' credit lines available for durable goods purchases, also stimulated the purchase of entertainment goods.

Increasing women's bargaining power will lead to a reduction in the gap between production and entertainment goods ownership in Brazilian households. Demographic trends will tend to improve women's bargaining power, but at a slow pace (Oliveira, Albuquerque, and Lins (2004)). Because men tend to marry younger women, as population growth slows, 
there are fewer women in the younger cohort, increasing women's bargaining power. Improvements in women's level of education will be the most important channel to increase the ownership of household-production durable goods, especially the more expensive ones. Moreover, as the Brazilian population keeps ageing, there will be the need to increase female labor force participation to financially support the growth of the dependency ratio, as well as the need to increase the time spent on elderly care. Because women do most of the household work, there will be the need to increase the ownership of household-production durable goods to free up women's time and to improve women's well being. 


\section{References}

BEA (2008): "BEA Rates of Depreciation, Service Lives, Declining-Balance Rates, and Hulten-Wykoff categories," Discussion paper, Bureau of Economic Analysis (BEA).

Becker, G. S. (1965): "A Theory of the Allocation of Time," The Economic Journal, $75(299), 493-517$.

Cavalcanti, T. V., And J. Tavares (2008): "Assessing the "Engines of Liberation": Home Appliances and Female Labor Force Participation," The Review of Economics and Statistics, 90(1), 81-88.

Deaton, A., And J. Muellbauer (1980): Economics and Consumer Behavior. Cambridge University Press.

Deaton, A., And S. ZAidi (2002): "Guidelines for Constructing Consumption Aggreagtes for Welfare Analysis," Living Standards Measurement Study Working Paper 135, The World Bank.

Fossett, M. A., And K. J. Kiecolt (1991): "A Methodological Review of the Sex Ratio: Alternatives for Comparative Research," Journal of Marriage and the Family, $53(4), 941-957$.

Greenwood, J., A. Seshadri, and M. Yorukoglu (2005): "Engines of Liberation," Review of Economic Studies, 72(1), 109-133.

Jones, L. E., R. E. Manuelli, and E. R. McGrattan (2003): "Why Are Married Women Working So Much?," Research Department Staff Report 317, Federal Reserve Bank of Minneapolis.

Jornal Estado de SĀo Paulo (2009): "Mantega confirma reduçāO de IPI da linha branca, 17 de abril de 2009," Discussion paper, Jornal Estado de Sāo Paulo. 
Kanczuk, F., and F. FAria Jr. (2000): "Ciclos Reais para a Indústria Brasileira?," Estudos Econômicos (IPE/USP), 30(3), 335-350.

Lundberg, S., and R. A. Pollak (1993): "Separate-Spheres Bargaining and the Marriage Market," Journal of Political Economy, 6, 988-1010.

Lundberg, S. J., R. A. Pollak, and T. J. Wales (1997): "Do Husbands and Wives Pool Their Resources? Evidence from the United Kingdom Child Benefit," The Journal of Human Resources, 32(3), 463-480.

Manser, M., And M. Brown (1980): "Marriage and Household Decision-Making: A Bargaining Analysis," International Economic Review, 21(1), 31-44.

McElroy, M., And M. J. Horney (1981): "Nash-Bargained Household Decisions: Towards a Generalization of the Theory of Demand," International Economic Review, 22(2), 333-349.

Oliveira, J. D. C., F. R. P. D. C. E. Albuquerque, and I. B. Lins (2004): "Projeçāo da populaçāo do Brasil por sexo e idade para o período 1980 a 2050: revisāo 2004.," Discussion paper, Instituto Brasileiro de Geografia e Estatística (IBGE).

OliveiRA, R. D. (2000): "For a fair sharing of time - Brazil households," UNESCO Courier.

Thomas, D. (1990): "Intra-Household Resouce Allocation: An Inferential Approach," The Journal of Human Resources, 25(4), 635-664.

(1997): Income, Expenditure, and Health Outcomes: Evidence on Intrahousehold Resource Allocation,chap. Intrahousehold allocation in Developing Countries: Models, Methods, and Policy, pp. 142-164. Johns Hopkins University Press. 
UOL ONLINE (2009): "Governo reduz IPI de geladeira, fogo, mquina de lavar e tanquinho, 17 de abril de 2009," Discussion paper, UOL online. 
Table 1: Descriptive Statistics, Brazil, 2002-2003.

\begin{tabular}{|c|c|c|}
\hline Variable & Mean & Std. Dev. \\
\hline \multicolumn{3}{|l|}{$\underline{\text { Dependent Variables }}$} \\
\hline Relative Ownership Indicator & 1.08 & $(0.64)$ \\
\hline Number of Production Goods & 2.63 & $(1.44)$ \\
\hline Number of Entertainment Goods & 2.89 & $(1.99)$ \\
\hline Rental Value Share & 1.29 & $(2.05)$ \\
\hline \multicolumn{3}{|l|}{ Bargaining Power Variables } \\
\hline Marriage Market, same cohort & 1.07 & $(0.10)$ \\
\hline Marriage Market, wife in younger cohort & 1.21 & $(0.13)$ \\
\hline Both make expenditure decisions & 0.82 & $(0.39)$ \\
\hline Only wife makes expenditure decisions & 0.02 & $(0.14)$ \\
\hline Only husband makes expenditure decisions & 0.16 & $(0.37)$ \\
\hline Wife has more education & 0.42 & $(0.49)$ \\
\hline Husband has more education & 0.31 & $(0.46)$ \\
\hline Wife's Age & 33.45 & $(7.59)$ \\
\hline Wife has no schooling & 0.07 & $(0.26)$ \\
\hline Wife has primary education & 0.32 & $(0.47)$ \\
\hline Wife has secondary education & 0.29 & $(0.45)$ \\
\hline Wife has high school & 0.25 & $(0.43)$ \\
\hline Wife has college or more & 0.07 & $(0.26)$ \\
\hline Husband's Age & 36.53 & $(7.55)$ \\
\hline Husband has no schooling & 0.10 & $(0.31)$ \\
\hline Husband has primary education & 0.35 & $(0.48)$ \\
\hline Husband has secondary education & 0.27 & $(0.44)$ \\
\hline Husband has high school & 0.21 & $(0.41)$ \\
\hline Husband has college or more & 0.07 & $(0.25)$ \\
\hline \multicolumn{3}{|l|}{ Household Variables } \\
\hline Number of Families in $\mathrm{HH}$ & 1.00 & $(0.06)$ \\
\hline Number of People in Household & 4.23 & $(1.56)$ \\
\hline Per capita total monthly income & 418.01 & $(781.53)$ \\
\hline Average State Income (in 1000) & 0.89 & $(0.28)$ \\
\hline \multicolumn{3}{|l|}{$\underline{\text { Prices }}$} \\
\hline Rental Value of Entertainment Durable Goods & 9.31 & $(1.02)$ \\
\hline Rental Value of Production Durable Goods & 4.59 & $(0.42)$ \\
\hline Price of an hour of maid's services & 0.93 & $(0.25)$ \\
\hline Price of electricity (kwatts) & 0.21 & $(0.02)$ \\
\hline Number of Observations & 19662 & \\
\hline
\end{tabular}

Source: POF 2002-2003 and PNAD 2001. 


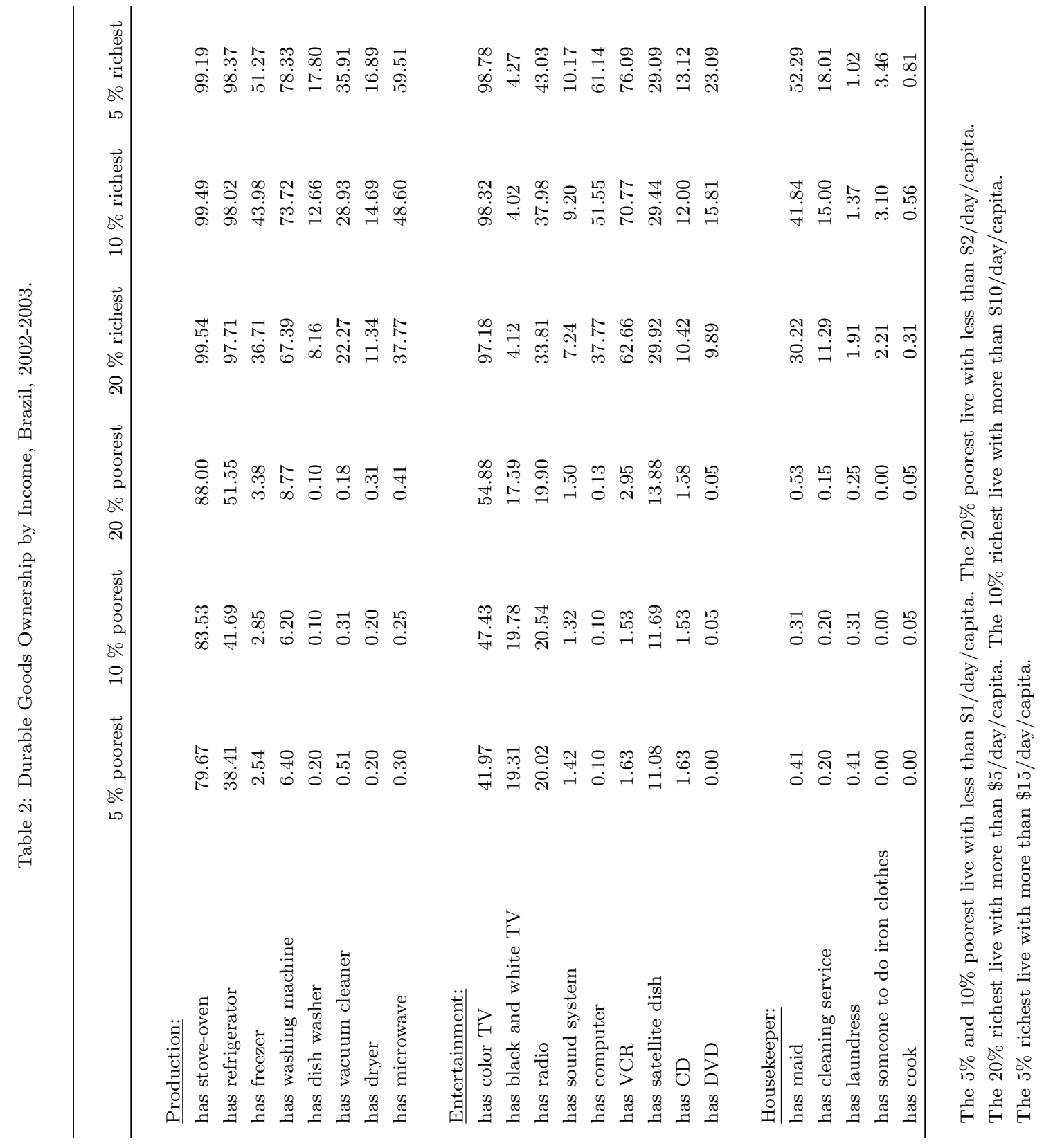


Table 3: Durable Goods Costs as Forgone Households Monthly Expenditures, Brazil 2002-2003.

\begin{tabular}{lccccc}
\hline & & & & & \\
& lower & lower-Middle & middle & upper-middle & higher \\
& & & & & \\
\hline & & & & & \\
Microwave & 1.38 & 0.75 & 0.49 & 0.30 & 0.10 \\
Dryer & 0.91 & 0.54 & 0.37 & 0.23 & 0.08 \\
Washing Machine & 1.49 & 0.78 & 0.50 & 0.31 & 0.10 \\
Vacuum Cleaner & 0.52 & 0.29 & 0.20 & 0.12 & 0.04 \\
Dish Washer & 1.47 & 0.88 & 0.61 & 0.37 & 0.12 \\
Refrigerator & 2.56 & 1.39 & 0.91 & 0.55 & 0.18 \\
Freezer & 2.82 & 1.45 & 0.91 & 0.55 & 0.17 \\
Stoven/Oven & 0.96 & 0.54 & 0.37 & 0.23 & 0.07 \\
TV & 2.05 & 1.13 & 0.74 & 0.46 & 0.15 \\
Black-White TV & 0.54 & 0.29 & 0.18 & 0.12 & 0.04 \\
Sound System & 1.64 & 0.89 & 0.58 & 0.35 & 0.11 \\
Radio & 0.23 & 0.14 & 0.10 & 0.06 & 0.02 \\
PC & 7.09 & 3.76 & 2.41 & 1.46 & 0.47 \\
VCR & 1.30 & 0.70 & 0.46 & 0.28 & 0.09 \\
Satellite & 1.26 & 0.68 & 0.44 & 0.27 & 0.09 \\
CD player & 1.44 & 0.77 & 0.49 & 0.30 & 0.10 \\
DVD player & 1.84 & 1.00 & 0.65 & 0.40 & 0.13 \\
\hline \hline
\end{tabular}

Source: POF 2002-2003 
Table 4: Main Results. Dependent Variable: Share of Rental Value of Production to Entertainment Durable Goods, share $_{p / e}$, Brazil, 2002-2003

\begin{tabular}{|c|c|c|}
\hline & OLS & Tobit \\
\hline \multicolumn{3}{|l|}{ Bargaining Power Variables } \\
\hline \multirow[t]{2}{*}{ Marriage Market } & -0.5088 & -0.5066 \\
\hline & $(0.1639)^{* * *}$ & $(0.1669)^{* * *}$ \\
\hline \multirow[t]{2}{*}{ Only wife makes decisions about expenditures } & 0.1839 & 0.1893 \\
\hline & $(0.0869)^{* *}$ & $(0.0884)^{* *}$ \\
\hline \multirow{2}{*}{ Only husband makes decisions about expenditures } & 0.3081 & 0.2959 \\
\hline & $(0.0441)^{* * *}$ & $(0.0454)^{* * *}$ \\
\hline \multirow[t]{2}{*}{ Wife's Age } & -0.0038 & -0.0036 \\
\hline & $(0.0028)$ & $(0.0029)$ \\
\hline \multirow[t]{2}{*}{ Husband's age - wife's age } & -0.0026 & -0.0022 \\
\hline & $(0.0030)$ & $(0.0030)$ \\
\hline \multirow[t]{2}{*}{ Wife has more schooling } & 0.1302 & 0.1321 \\
\hline & $(0.0381)^{* * *}$ & $(0.0388)^{* * *}$ \\
\hline \multirow[t]{2}{*}{ Husband has more schooling } & -0.0262 & -0.0034 \\
\hline & $(0.0398)$ & $(0.0427)$ \\
\hline \multirow[t]{2}{*}{ Wife has primary education } & -0.0547 & 0.0035 \\
\hline & $(0.0765)$ & $(0.0878)$ \\
\hline \multirow[t]{2}{*}{ Wife has middle school } & -0.2086 & -0.1183 \\
\hline & $(0.0859)^{* *}$ & $(0.0982)$ \\
\hline \multirow[t]{2}{*}{ Wife has high school } & -0.3326 & -0.2324 \\
\hline & $(0.0911)^{* * *}$ & $(0.1050)^{* *}$ \\
\hline \multirow[t]{2}{*}{ Wife has college } & -0.6134 & -0.5166 \\
\hline & $(0.1092)^{* * *}$ & $(0.1204)^{* * *}$ \\
\hline \multicolumn{3}{|l|}{ Household Variables } \\
\hline \multirow[t]{2}{*}{ Number of girls $0-3$ years old in $\mathrm{HH}$} & 0.0785 & 0.0525 \\
\hline & $(0.0344)^{* *}$ & $(0.0356)$ \\
\hline \multirow[t]{2}{*}{ Number of girls $4-6$ years old in $\mathrm{HH}$} & -0.0823 & -0.0945 \\
\hline & $(0.0387)^{* *}$ & $(0.0416)^{* *}$ \\
\hline \multirow[t]{2}{*}{ Number of girls $7-12$ years old in $\mathrm{HH}$} & 0.0065 & -0.0005 \\
\hline & $(0.0287)$ & $(0.0297)$ \\
\hline \multirow[t]{2}{*}{ Number of girls $13-16$ years old in $\mathrm{HH}$} & -0.0345 & -0.0442 \\
\hline & $(0.0345)$ & $(0.0355)$ \\
\hline \multirow[t]{2}{*}{ Number of women 17-19 years old in $\mathrm{HH}$} & -0.0757 & -0.0758 \\
\hline & $(0.0475)$ & $(0.0471)$ \\
\hline \multirow[t]{2}{*}{ Number of women 51-60 years old in $\mathrm{HH}$} & -0.0234 & -0.01 \\
\hline & $(0.1393)$ & $(0.1421)$ \\
\hline \multirow[t]{2}{*}{ Number of women $61-70$ years old in $\mathrm{HH}$} & -0.199 & -0.2135 \\
\hline & $(0.1212)$ & $(0.1286)^{*}$ \\
\hline \multirow[t]{2}{*}{ Number of women older than 70 years in $\mathrm{HH}$} & 0.031 & 0.032 \\
\hline & $(0.1640)$ & $(0.1671)$ \\
\hline \multirow[t]{2}{*}{ Number of boys $0-3$ years old in $\mathrm{HH}$} & 0.1703 & 0.1536 \\
\hline & \multicolumn{2}{|c|}{ Continued on next page } \\
\hline
\end{tabular}


Table 4 - continued from previous page

\begin{tabular}{|c|c|c|}
\hline & OLS & Tobit \\
\hline & $(0.0371)^{* * *}$ & $(0.0385)^{* * *}$ \\
\hline \multirow[t]{2}{*}{ Number of boys $4-6$ years old in $\mathrm{HH}$} & 0.0284 & 0.0146 \\
\hline & $(0.0450)$ & $(0.0465)$ \\
\hline \multirow[t]{2}{*}{ Number of boys $7-12$ years old in $\mathrm{HH}$} & -0.0011 & -0.0071 \\
\hline & $(0.0269)$ & $(0.0271)$ \\
\hline \multirow[t]{2}{*}{ Number of boys $13-16$ years old in $\mathrm{HH}$} & -0.0241 & -0.0299 \\
\hline & $(0.0378)$ & $(0.0383)$ \\
\hline \multirow[t]{2}{*}{ Number of men 17-19 years old in $\mathrm{HH}$} & -0.0101 & -0.0097 \\
\hline & $(0.0389)$ & $(0.0394)$ \\
\hline \multirow[t]{2}{*}{ Number of men 51-60 years old in $\mathrm{HH}$} & -0.1939 & -0.219 \\
\hline & $(0.1573)$ & $(0.1629)$ \\
\hline \multirow[t]{2}{*}{ Number of men $61-70$ years old in $\mathrm{HH}$} & -0.177 & -0.1542 \\
\hline & $(0.1323)$ & $(0.1278)$ \\
\hline \multirow[t]{2}{*}{ Number of men older than 70 years in $\mathrm{HH}$} & -0.1133 & -0.1317 \\
\hline & $(0.1207)$ & $(0.1305)$ \\
\hline \multirow[t]{2}{*}{ Number of families in $\mathrm{HH}$} & -0.1618 & -0.2265 \\
\hline & $(0.2161)$ & $(0.2358)$ \\
\hline \multirow{2}{*}{ Per Capita Income (in 1000) } & -0.0921 & -0.094 \\
\hline & $(0.0146)^{* * *}$ & $(0.0149)^{* * *}$ \\
\hline \multicolumn{3}{|l|}{$\underline{\text { State Level Variables }}$} \\
\hline \multirow[t]{2}{*}{ Proportion of Working Women by State and Cohort } & 0.12 & 0.0854 \\
\hline & $(0.2956)$ & $(0.2993)$ \\
\hline \multirow[t]{2}{*}{ Average State Income (in 1000) } & -0.1255 & -0.1511 \\
\hline & $(0.2558)$ & $(0.2584)$ \\
\hline \multirow[t]{2}{*}{ Price of maids } & 0.3701 & 0.4174 \\
\hline & $(0.2361)$ & $(0.2385)^{*}$ \\
\hline \multicolumn{3}{|l|}{ Region Level Variables } \\
\hline \multirow[t]{2}{*}{$\overline{\text { Price of production goods }}$} & 0.5869 & 0.6296 \\
\hline & $(0.2161)^{* *}$ & $(0.2162)^{* * *}$ \\
\hline \multirow[t]{2}{*}{ Price of entertainment goods } & -0.1535 & -0.1712 \\
\hline & $(0.0912)$ & $(0.0920)^{*}$ \\
\hline \multirow[t]{2}{*}{ Price of electricity (in kwatts) } & 3.1705 & 3.8095 \\
\hline & $(3.3992)$ & $(3.4963)$ \\
\hline \multirow[t]{2}{*}{ Constant } & 0.0308 & -0.1672 \\
\hline & $(0.9038)$ & $(0.9078)$ \\
\hline Observations & 19662 & 19662 \\
\hline R-squared & 0.0251 & \\
\hline
\end{tabular}

Standard errors in parentheses.

* significant at $10 \%$; ** significant at $5 \% ; * * *$ significant at $1 \%$. 
Table 5: Main Results. Dependent Variable: Ratio of Production to Enter-

tainment Durable Goods, own $/$, , Brazil, 2002-2003.

OLS

Tobit

Bargaining Power Variables

Marriage Market

$\begin{array}{cc}-0.4158 & -0.4156 \\ (0.1439)^{* * *} & (0.1452)^{* * *} \\ 0.0964 & 0.0976 \\ (0.0391)^{* *} & (0.0397)^{* *} \\ 0.0446 & 0.0417 \\ (0.0240)^{*} & (0.0245)^{*} \\ -0.0035 & -0.0035 \\ (0.0010)^{* * *} & (0.0010)^{* * *} \\ -0.0021 & -0.002 \\ (0.0010)^{*} & (0.0010)^{*} \\ 0.0202 & 0.0207 \\ (0.0142) & (0.0145) \\ 0.0033 & 0.0085 \\ (0.0141) & (0.0148) \\ 0.0371 & 0.0507 \\ (0.0226) & (0.0253)^{* *} \\ 0.0769 & 0.0976 \\ (0.0295)^{* *} & (0.0330)^{* * *} \\ -0.001 & 0.0217 \\ (0.0383) & (0.0415) \\ -0.1674 & -0.1454 \\ (0.0441)^{* * *} & (0.0468)^{* * *}\end{array}$

$\underline{\text { Household Variables }}$

Number of girls 0-3 years old in $\mathrm{HH}$

$0.0046 \quad-0.0013$

Number of girls 4-6 years old in $\mathrm{HH}$

$(0.0119) \quad(0.0127)$

$-0.0236 \quad-0.0263$

$(0.0134)^{*} \quad(0.0142)^{*}$

Number of girls 7-12 years old in $\mathrm{HH}$

$-0.0116 \quad-0.0133$

$(0.0080) \quad(0.0084)$
-0.0205

Number of girls 13-16 years old in $\mathrm{HH}$

$-0.0205 \quad-0.0227$

Number of women 17-19 years old in $\mathrm{HH}$

$(0.0092)^{* *} \quad(0.0095)^{* *}$

$-0.0113 \quad-0.0114$

$(0.0128) \quad(0.0130)$

Number of women 51-60 years old in $\mathrm{HH}$

$-0.011 \quad-0.0081$

$(0.0483) \quad(0.0491)$

Number of women 61-70 years old in $\mathrm{HH}$

$-0.1189 \quad-0.1221$

Number of women older than 70 years in $\mathrm{HH}$

\begin{tabular}{cc}
$(0.0445)^{* *}$ & $(0.0467)^{* * *}$ \\
0.0086 & 0.0088 \\
$(0.0524)$ & $(0.0534)$ \\
\multicolumn{2}{c}{ Continued on next page }
\end{tabular}


Table 5 - continued from previous page

\begin{tabular}{|c|c|c|}
\hline & OLS & Tobit \\
\hline Number of boys $0-3$ years old in $\mathrm{HH}$ & $\begin{array}{c}0.0244 \\
(0.0132)^{*}\end{array}$ & $\begin{array}{c}0.0205 \\
(0.0137)\end{array}$ \\
\hline Number of boys $4-6$ years old in $\mathrm{HH}$ & $\begin{array}{l}-0.0101 \\
(0.0141)\end{array}$ & $\begin{array}{l}-0.0133 \\
(0.0144)\end{array}$ \\
\hline Number of boys $7-12$ years old in $\mathrm{HH}$ & $\begin{array}{c}-0.015 \\
(0.0085)^{*}\end{array}$ & $\begin{array}{c}-0.0164 \\
(0.0086)^{*}\end{array}$ \\
\hline Number of boys $13-16$ years old in $\mathrm{HH}$ & $\begin{array}{c}-0.0158 \\
(0.0086)^{*}\end{array}$ & $\begin{array}{c}-0.0171 \\
(0.0086)^{* *}\end{array}$ \\
\hline Number of men 17-19 years old in $\mathrm{HH}$ & $\begin{array}{l}-0.0107 \\
(0.0141)\end{array}$ & $\begin{array}{l}-0.0106 \\
(0.0143)\end{array}$ \\
\hline Number of men 51-60 years old in $\mathrm{HH}$ & $\begin{array}{l}-0.0661 \\
(0.0993)\end{array}$ & $\begin{array}{l}-0.0718 \\
(0.1033)\end{array}$ \\
\hline Number of men $61-70$ years old in $\mathrm{HH}$ & $\begin{array}{c}0.0349 \\
(0.0625)\end{array}$ & $\begin{array}{c}0.0399 \\
(0.0625)\end{array}$ \\
\hline Number of men older than 70 years in $\mathrm{HH}$ & $\begin{array}{l}-0.0236 \\
(0.0562)\end{array}$ & $\begin{array}{l}-0.0276 \\
(0.0576)\end{array}$ \\
\hline Number of families in $\mathrm{HH}$ & $\begin{array}{c}0.0107 \\
(0.0620)\end{array}$ & $\begin{array}{l}-0.0024 \\
(0.0656)\end{array}$ \\
\hline Per Capita Income (in 1000) & $\begin{array}{c}-0.0421 \\
(0.0099)^{* * *}\end{array}$ & $\begin{array}{c}-0.0425 \\
(0.0100)^{* * *}\end{array}$ \\
\hline \multicolumn{3}{|l|}{ State Level Variables } \\
\hline Proportion of Working Women by State and Cohort & $\begin{array}{c}0.1209 \\
(0.1928)\end{array}$ & $\begin{array}{c}0.1129 \\
(0.1940)\end{array}$ \\
\hline Average State Income (in 1000) & $\begin{array}{l}-0.0856 \\
(0.1880)\end{array}$ & $\begin{array}{l}-0.0916 \\
(0.1890)\end{array}$ \\
\hline Price of maids & $\begin{array}{c}0.412 \\
(0.1875)^{* *}\end{array}$ & $\begin{array}{c}0.4227 \\
(0.1893)^{* *}\end{array}$ \\
\hline \multicolumn{3}{|l|}{$\underline{\text { Region Level Variables }}$} \\
\hline Price of production goods & $\begin{array}{c}0.5224 \\
(0.1647)^{* * *}\end{array}$ & $\begin{array}{c}0.532 \\
(0.1650)^{* * *}\end{array}$ \\
\hline price of entertainment goods & $\begin{array}{c}-0.1997 \\
(0.0671)^{* * *}\end{array}$ & $\begin{array}{c}-0.2036 \\
(0.0673)^{* * *}\end{array}$ \\
\hline price of electricity (in kwatts) & $\begin{array}{c}4.1397 \\
(2.8111)\end{array}$ & $\begin{array}{c}4.2852 \\
(2.8425)\end{array}$ \\
\hline Constant & $\begin{array}{l}-0.1506 \\
(0.6978)\end{array}$ & $\begin{array}{l}-0.1973 \\
(0.7040)\end{array}$ \\
\hline Observations & 19662 & 19662 \\
\hline R-squared & 0.0868 & \\
\hline
\end{tabular}

Standard errors in parentheses.

* significant at $10 \% ; * *$ significant at $5 \% ; * * *$ significant at $1 \%$. 
Table 6: Results Using Alternatives Measures of Marriage Market,

Brazil, 2002-2003.

Dependent Variable: share $_{p / e} \quad$ Dependent Variable: $o w n_{p / e}$

Marriage Market Variables:

Women in younger cohort

$-0.1461$

$-0.2658$

$(0.1603)$

$(0.1112)^{* *}$

By education level:

Merged by wife's education

Merged by husband's education

Other Bargaining Variables

$\underline{\text { Household Variables }}$

$\underline{\text { State Level Variables }}$

$\underline{\text { Region Level Variables }}$

Observations

R-squared

$$
\begin{gathered}
0.0876 \\
(0.0938)
\end{gathered}
$$

$-0.1650$

$(0.0699)^{* *}$

yes

yes

yes

yes

yes

yes

yes

yes

yes

yes

$19662 \quad 19662$

0.0246

0.0245

yes

yes

yes

0.0261

(0.0507)

$-0.1147$

$(0.0449)^{* *}$

Standard errors in parentheses.

* significant at $10 \%$;* significant at $5 \%$; ** significant at $1 \%$. 
Table 7: Results by Income Group. Dependent Variable: Share of Rental Value

of Production to Entertainment Durable Goods, share p $_{\text {e }}$, Brazil, 2002-2003.

\begin{tabular}{|c|c|c|c|c|c|}
\hline & low & lower middle & middle & upper middle & high \\
\hline \multicolumn{6}{|l|}{$\underline{\text { Bargaining Power Variables }}$} \\
\hline Marriage Market & $\begin{array}{c}-0.6683 \\
(0.3069)^{* *}\end{array}$ & $\begin{array}{c}-0.493 \\
(0.3293)\end{array}$ & $\begin{array}{c}-0.6014 \\
(0.3048)^{*}\end{array}$ & $\begin{array}{l}-0.3705 \\
(0.3504)\end{array}$ & $\begin{array}{c}-0.3986 \\
(0.1752)^{* *}\end{array}$ \\
\hline Only wife makes decisions about expenditures & $\begin{array}{l}-0.0273 \\
(0.2725)\end{array}$ & $\begin{array}{c}0.2791 \\
(0.1549)^{*}\end{array}$ & $\begin{array}{c}0.131 \\
(0.2582)\end{array}$ & $\begin{array}{c}0.2714 \\
(0.1959)\end{array}$ & $\begin{array}{c}0.1019 \\
(0.2680)\end{array}$ \\
\hline Only husband makes decisions about expenditures & $\begin{array}{c}0.3382 \\
(0.0745)^{* * *}\end{array}$ & $\begin{array}{c}0.2587 \\
(0.0952)^{* *}\end{array}$ & $\begin{array}{c}0.3296 \\
(0.1122)^{* * *}\end{array}$ & $\begin{array}{c}0.1933 \\
(0.1150)\end{array}$ & $\begin{array}{c}0.2254 \\
(0.1199) *\end{array}$ \\
\hline Wife's Age & $\begin{array}{c}0.0162 \\
(0.0087)^{*}\end{array}$ & $\begin{array}{c}0.009 \\
(0.0085)\end{array}$ & $\begin{array}{c}-0.0122 \\
(0.0052)^{* *}\end{array}$ & $\begin{array}{l}-0.0052 \\
(0.0038)\end{array}$ & $\begin{array}{l}-0.0084 \\
(0.0050)\end{array}$ \\
\hline Husband's age - wife's age & $\begin{array}{c}0.0131 \\
(0.0087)\end{array}$ & $\begin{array}{c}0.005 \\
(0.0081)\end{array}$ & $\begin{array}{l}-0.0042 \\
(0.0072)\end{array}$ & $\begin{array}{c}-0.012 \\
(0.0059)^{*}\end{array}$ & $\begin{array}{l}-0.0067 \\
(0.0049)\end{array}$ \\
\hline Wife has more schooling & $\begin{array}{l}-0.0704 \\
(0.1180)\end{array}$ & $\begin{array}{l}-0.0013 \\
(0.1080)\end{array}$ & $\begin{array}{c}0.1232 \\
(0.0766)\end{array}$ & $\begin{array}{c}0.1841 \\
(0.0502)^{* * *}\end{array}$ & $\begin{array}{c}0.1572 \\
(0.0542)^{* * *}\end{array}$ \\
\hline Husband has more schooling & $\begin{array}{l}-0.1473 \\
(0.1198)\end{array}$ & $\begin{array}{l}-0.1211 \\
(0.1346)\end{array}$ & $\begin{array}{l}-0.0098 \\
(0.0890)\end{array}$ & $\begin{array}{c}0.1761 \\
(0.0586)^{* * *}\end{array}$ & $\begin{array}{l}-0.0638 \\
(0.0530)\end{array}$ \\
\hline Wife has primary education & $\begin{array}{c}0.0715 \\
(0.1272)\end{array}$ & $\begin{array}{l}-0.0805 \\
(0.1173)\end{array}$ & $\begin{array}{c}0.0613 \\
(0.1618)\end{array}$ & $\begin{array}{c}0.0135 \\
(0.2477)\end{array}$ & $\begin{array}{l}-0.4882 \\
(0.4691)\end{array}$ \\
\hline Wife has secondary education & $\begin{array}{c}0.1063 \\
(0.1647)\end{array}$ & $\begin{array}{l}-0.1786 \\
(0.1490)\end{array}$ & $\begin{array}{c}-0.2063 \\
(0.1638)\end{array}$ & $\begin{array}{l}-0.1317 \\
(0.2187)\end{array}$ & $\begin{array}{l}-0.6041 \\
(0.4199)\end{array}$ \\
\hline Wife has high school & $\begin{array}{c}0.2665 \\
(0.2344)\end{array}$ & $\begin{array}{l}-0.2267 \\
(0.1830)\end{array}$ & $\begin{array}{l}-0.1111 \\
(0.1878)\end{array}$ & $\begin{array}{l}-0.2384 \\
(0.2417)\end{array}$ & $\begin{array}{c}-0.7772 \\
(0.4368)^{*}\end{array}$ \\
\hline Wife has college & $\begin{array}{c}-0.2023 \\
(0.3786)\end{array}$ & $\begin{array}{c}0.1114 \\
(0.7881)\end{array}$ & $\begin{array}{c}-0.2906 \\
(0.2882)\end{array}$ & $\begin{array}{c}-0.5028 \\
(0.2402)^{* *}\end{array}$ & $\begin{array}{c}-0.9689 \\
(0.4378)^{* *}\end{array}$ \\
\hline$\underline{\text { Household Variables }}$ & yes & yes & yes & yes & yes \\
\hline$\underline{\text { State Level Variables }}$ & yes & yes & yes & yes & yes \\
\hline$\underline{\text { Region Level Variables }}$ & yes & yes & yes & yes & yes \\
\hline Observations & 3933 & 3932 & 3933 & 3932 & 3932 \\
\hline R-squared & 0.0274 & 0.0181 & 0.0208 & 0.0247 & 0.0469 \\
\hline
\end{tabular}

Standard errors in parentheses.

* significant at $10 \%$; ${ }^{*}$ significant at $5 \% ;{ }^{* * *}$ significant at $1 \%$. 
Table 8: Results by Income Group. Dependent Variable: Ratio of Production

to Entertainment Durable Goods, own $/$, , Brazil, 2002-2003.

\begin{tabular}{|c|c|c|c|c|c|}
\hline & low & lower middle & middle & upper middle & high \\
\hline \multicolumn{6}{|l|}{$\underline{\text { Bargaining Power Variables }}$} \\
\hline Marriage Market & $\begin{array}{c}-0.3093 \\
(0.1549)^{*}\end{array}$ & $\begin{array}{c}-0.3646 \\
(0.1606)^{* *}\end{array}$ & $\begin{array}{c}-0.6019 \\
(0.2158)^{* * *}\end{array}$ & $\begin{array}{c}-0.3981 \\
(0.2285)^{*}\end{array}$ & $\begin{array}{c}-0.3372 \\
(0.0999)^{* * *}\end{array}$ \\
\hline Only wife makes decisions about expenditures & $\begin{array}{c}0.0452 \\
(0.0882)\end{array}$ & $\begin{array}{c}0.1736 \\
(0.0883)^{*}\end{array}$ & $\begin{array}{c}0.1055 \\
(0.0772)\end{array}$ & $\begin{array}{c}0.0162 \\
(0.0566)\end{array}$ & $\begin{array}{c}0.0824 \\
(0.0788)\end{array}$ \\
\hline Only husband makes decisions about expenditures & $\begin{array}{c}0.0326 \\
(0.0277)\end{array}$ & $\begin{array}{c}0.0665 \\
(0.0343) *\end{array}$ & $\begin{array}{c}0.0377 \\
(0.0327)\end{array}$ & $\begin{array}{c}0.0251 \\
(0.0528)\end{array}$ & $\begin{array}{c}0.1013 \\
(0.0312)^{* * *}\end{array}$ \\
\hline Wife's Age & $\begin{array}{c}0.0027 \\
(0.0025)\end{array}$ & $\begin{array}{c}0.0005 \\
(0.0022)\end{array}$ & $\begin{array}{c}-0.0034 \\
(0.0017)^{*}\end{array}$ & $\begin{array}{c}-0.0055 \\
(0.0014)^{* * *}\end{array}$ & $\begin{array}{c}-0.0059 \\
(0.0016)^{* * *}\end{array}$ \\
\hline Husband's age - wife's age & $\begin{array}{c}0.0026 \\
(0.0026)\end{array}$ & $\begin{array}{l}-0.0015 \\
(0.0021)\end{array}$ & $\begin{array}{c}0.001 \\
(0.0022)\end{array}$ & $\begin{array}{c}-0.002 \\
(0.0027)\end{array}$ & $\begin{array}{c}-0.0062 \\
(0.0024)^{* *}\end{array}$ \\
\hline Wife has more schooling & $\begin{array}{c}-0.0531 \\
(0.0214)^{* *}\end{array}$ & $\begin{array}{l}-0.0101 \\
(0.0288)\end{array}$ & $\begin{array}{c}0.0101 \\
(0.0242)\end{array}$ & $\begin{array}{c}0.0257 \\
(0.0230)\end{array}$ & $\begin{array}{c}0.0341 \\
(0.0313)\end{array}$ \\
\hline Husband has more schooling & $\begin{array}{c}0.0286 \\
(0.0323)\end{array}$ & $\begin{array}{c}0.048 \\
(0.0305)\end{array}$ & $\begin{array}{l}-0.0082 \\
(0.0330)\end{array}$ & $\begin{array}{l}-0.0337 \\
(0.0202)\end{array}$ & $\begin{array}{c}-0.0518 \\
(0.0197)^{* *}\end{array}$ \\
\hline Wife has primary education & $\begin{array}{c}0.0981 \\
(0.0306)^{* * *}\end{array}$ & $\begin{array}{c}0.0208 \\
(0.0344)\end{array}$ & $\begin{array}{c}0.0137 \\
(0.0488)\end{array}$ & $\begin{array}{c}-0.016 \\
(0.0754)\end{array}$ & $\begin{array}{l}-0.0679 \\
(0.1603)\end{array}$ \\
\hline Wife has secondary education & $\begin{array}{c}0.2763 \\
(0.0373)^{* * *}\end{array}$ & $\begin{array}{c}0.102 \\
(0.0406)^{* *}\end{array}$ & $\begin{array}{c}0.0086 \\
(0.0488)\end{array}$ & $\begin{array}{l}-0.0553 \\
(0.0696)\end{array}$ & $\begin{array}{l}-0.1543 \\
(0.1386)\end{array}$ \\
\hline Wife has high school & $\begin{array}{c}0.2532 \\
(0.0533)^{* * *}\end{array}$ & $\begin{array}{c}0.1299 \\
(0.0497)^{* *}\end{array}$ & $\begin{array}{l}-0.0052 \\
(0.0485)\end{array}$ & $\begin{array}{l}-0.1273 \\
(0.0844)\end{array}$ & $\begin{array}{c}-0.2747 \\
(0.1595)^{*}\end{array}$ \\
\hline Wife has college & $\begin{array}{c}0.3062 \\
(0.1882)\end{array}$ & $\begin{array}{c}0.1037 \\
(0.1537)\end{array}$ & $\begin{array}{l}-0.1103 \\
(0.0671)\end{array}$ & $\begin{array}{c}-0.2415 \\
(0.0809) * * *\end{array}$ & $\begin{array}{c}-0.3983 \\
(0.1566)^{* *}\end{array}$ \\
\hline$\underline{\text { Household Variables }}$ & yes & yes & yes & yes & yes \\
\hline$\underline{\text { State Level Variables }}$ & yes & yes & yes & yes & yes \\
\hline$\underline{\text { Region Level Variables }}$ & yes & yes & yes & yes & yes \\
\hline Observations & 3933 & 3932 & 3933 & 3932 & 3932 \\
\hline R-squared & 0.123 & 0.0823 & 0.0773 & 0.1037 & 0.1136 \\
\hline
\end{tabular}

Standard errors in parentheses.

* significant at $10 \% ; * *$ significant at $5 \% ; * *$ significant at $1 \%$. 
Figure 1: Number of Hours Worked Per Week (Only Employed Individuals).

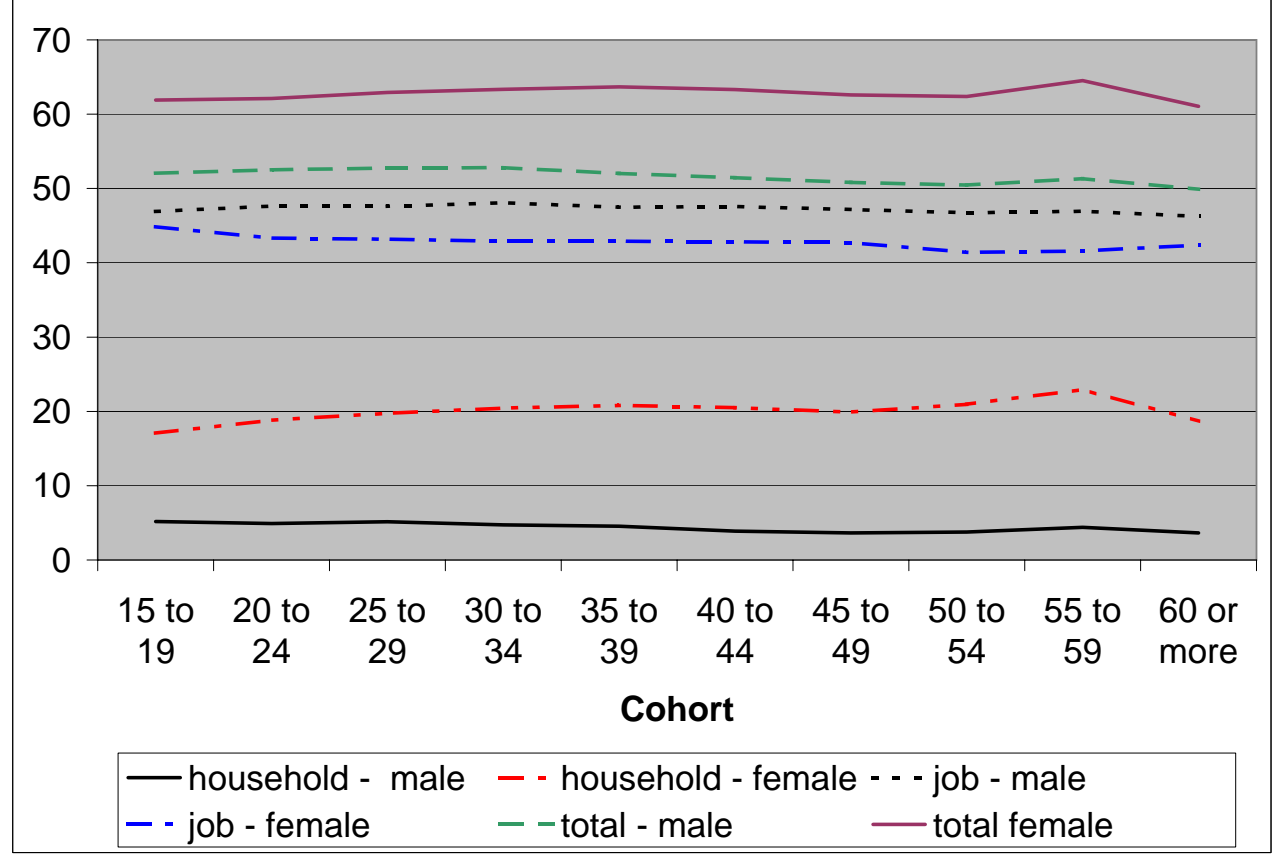

Source: PNAD 2001. 


\section{Appendix A Calculation of the expenditure ratio of durable goods}

A common way to measure the consumption of durable goods is to calculate their rental equivalent value. Here this rental equivalent measure is calculated using this model as well as using the empirical guides provided by Deaton and Zaidi (2002) to aggregate the values of production and entertainment categories. In the depreciation decay model, the rental equivalent value, $r v$, is estimated as

$$
r v=\frac{p}{2 T}(r-\pi+\delta)
$$

where $p$ is the average price of each durable good, $(r-\pi)$ is the real interest rate $^{7}, \delta$ is the depreciation rate, and $2 T$ is the average service life of these durable goods ${ }^{8}$.

There are no official estimates of the depreciation rate in Brazil. Some papers working with durable goods in Brazil ${ }^{9}$ argue that the depreciation rate in Brazil is equal to the US estimates. Usually, these papers use the US depreciation rate to deal with Brazilian aggregated durable goods data. The Bureau of Economic Analysis (BEA) estimates that the US depreciation rate for household appliances is 16.5\% (BEA (2008)). Information on the price of new and used durable goods is available in the POF for households who made a purchase during the survey period. Each household in the POF is asked about its stock of durable goods, allowing us to calculate the average time since last purchase of each

\footnotetext{
${ }^{7}$ The real interest rate used is the average of the 'selic' interest rate over 1979 to 2003 discounted by the average inflation rate during the same period. Both data come from IPEA, www.ipeadata.com. The average real interest rate is $5.6 \%$.

${ }^{8}$ Since the average service life is not observed in the sample, it is assumed that the life-time of durable goods is normally distributed. Therefore, the average service life is calculated as two times the average time since last purchase.

${ }^{9}$ For example: and Kanczuk and Faria Jr. (2000)
} 
durable good. By combining the information on purchase and stock of durable goods, the nominal depreciation rate is estimated by regressing the log of the average purchase price of each durable good in each State on the average time since last purchase in each State and a constant. The estimated nominal depreciation rate is about $10 \%{ }^{10}$, resulting in a real depreciation rate of approximately $15.6 \%$, similar to the BEA estimates for the US. This is the number used to calculate the rental equivalent value of the durable goods.

Finally, the rental value is summed over all of the household-production durable goods owned by the household, as well as for the entertainment durable goods owned by the household. Then a ratio of aggregated household-production expenditure to aggregated entertainment expenditure is generated. The relative expenditure on production to entertainment goods, share $_{p / e}$, is distributed as follows:

$\left(\right.$ A.2) share $_{p / e}=\left\{\begin{array}{l}y=0: \quad \text { no production and at least one entertainment good } \\ 0<y<1: \text { more entertainment than production goods } \\ y=1: \quad \text { same amount of production and entertainment goods } \\ 1<y \leq P D G: \text { more production than entertainment goods }\end{array}\right.$ where PDG is the tota expenditure onf production durable goods owned by the household. A household is assumed to have share $_{p / e}=P D G$ if has at least one production good and no entertainment good. This ratio is equal to zero if a household has no production good but has at least one entertainment good. The distribution of the expenditure ratio is censored at zero.

\footnotetext{
${ }^{10}$ See Table A.1 for estimates.
} 
Table A.1: Estimation of the Depreciation Rate for Consumer Durables, Brazil, 2002-2003 (Dependent Variable: Log of Average Price Per State).

\begin{tabular}{lccc}
\hline & $(1)$ & $(2)$ & $(3)$ \\
\hline \multirow{3}{*}{ Average Age } & & & \\
& $-0.1087^{* *}$ & $-0.1007^{* *}$ & $-0.1165^{* *}$ \\
Bought Used & $(0.0065)$ & $(0.0063)$ & $(0.0066)$ \\
& $-1.1667^{* *}$ & $-1.1547^{* *}$ & $-1.1547^{* *}$ \\
Unknown (Used or New) & $(0.0036)$ & $(0.0036)$ & $(0.0037)$ \\
& -0.7191 & $-0.8446^{*}$ & $-1.3161^{* *}$ \\
Constant & $(0.4124)$ & $(0.3593)$ & $(0.4268)$ \\
& $5.9182^{* *}$ & $5.8989^{* *}$ & $5.8989^{* *}$ \\
Observations & $(0.0016)$ & $(0.0016)$ & $(0.0017)$ \\
R-squared & 1508 & 1519 & 1506 \\
\hline \hline
\end{tabular}

Standard errors in parentheses.

* significant at $10 \%$; ${ }^{* *}$ significant at $5 \%$; ** significant at $1 \%$. Specification (1) includes the following: refrigerator, freezer, oven, washing machine, dryer, microwave, dishwasher, vacuum cleaner, TV, radio,sound system, VCR, CD player, DVD player, computer and satellite dish.

Specification (2) includes the durable goods in (1) plus new goods such as 'taquinho elétrico'.

Specification (3) includes the durable goods in (2) and more detailed categories of entertainment goods, such as: type of radio, sound system, DVD recorder. 
Table A.2: Proportion of Married People, Brazil, 2001.

\begin{tabular}{lcccc}
\hline & \multicolumn{2}{c}{ Men } & \multicolumn{2}{c}{ Women } \\
cohort & Mean & Std. Dev. & Mean & Std. Dev. \\
\hline 15 to 19 & 0.03 & $(0.16)$ & 0.14 & $(0.34)$ \\
20 to 24 & 0.26 & $(0.44)$ & 0.42 & $(0.49)$ \\
25 to 29 & 0.56 & $(0.50)$ & 0.63 & $(0.48)$ \\
30 to 34 & 0.73 & $(0.45)$ & 0.72 & $(0.45)$ \\
35 to 39 & 0.79 & $(0.41)$ & 0.74 & $(0.44)$ \\
40 to 44 & 0.82 & $(0.38)$ & 0.72 & $(0.45)$ \\
45 to 49 & 0.84 & $(0.37)$ & 0.69 & $(0.46)$ \\
50 to 54 & 0.85 & $(0.36)$ & 0.66 & $(0.47)$ \\
55 to 59 & 0.84 & $(0.37)$ & 0.61 & $(0.49)$ \\
60 or more & 0.78 & $(0.42)$ & 0.40 & $(0.49)$ \\
\hline \hline
\end{tabular}

Source: PNAD 2001. 
Table A.3: Wife's Average Age by Husband's Cohort, Brazil, 2001.

\begin{tabular}{lcc}
\hline Husband's Cohort & \multicolumn{2}{c}{ Wife's Age } \\
& Mean & Std. Dev. \\
\hline 15 to 19 & 19.41 & $(5.41)$ \\
20 to 24 & 22.14 & $(4.96)$ \\
25 to 29 & 25.77 & $(5.50)$ \\
30 to 34 & 29.72 & $(5.62)$ \\
35 to 39 & 33.86 & $(5.91)$ \\
40 to 44 & 38.08 & $(6.06)$ \\
45 to 49 & 42.68 & $(6.50)$ \\
\hline \hline
\end{tabular}

Source: PNAD 2001. 


\section{Appendix B Deriving Price and Income elasticities when the Dependent Variable ia a Ratio}

In this section, we derive expressions for the price and income elasticities of demand for the dependent variables. The first dependent variable is the ratio of expenditures on homeproduction durable goods to entertainment durable goods, share $_{p / e}$. The effect of the price of maids is easier to interpret if it is assumed that maids and entertainment goods are independent, i.e., the price of maids affects the expenditure on production goods but does not affect the expenditure on entertainment goods. The price elasticity of production goods with respect to price of maids is presented in equation B.1, and depends on the coefficient of the price of maids, $\alpha_{1}$, the price of maids, $P_{\text {maid }}$, and the relative expenditure of production to entertainment goods, share $e_{p / e}$. The coefficient of the price of maids indicates whether maids and production goods are substitutes, $\alpha_{1} i$, or complements, $\alpha_{1} i 0$. Notice also that the higher is $\alpha_{1}$ and $P_{\text {maid }}$, the more elastic is the expenditure on production goods relative to the price of maids. As well, the lower is the expenditure on production goods relative to expenditure on entertainment goods, the more elastic is the expenditure on production goods relative to the price of maids.

$$
\varepsilon_{\text {production }, P_{\text {maids }}}=\alpha_{1} \frac{P_{\text {maid }}}{\text { share }_{p / e}}
$$

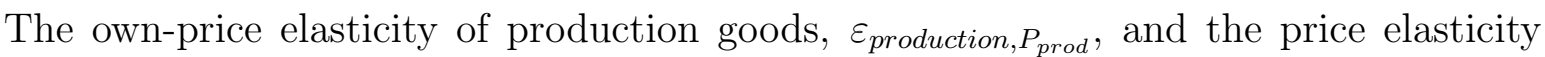

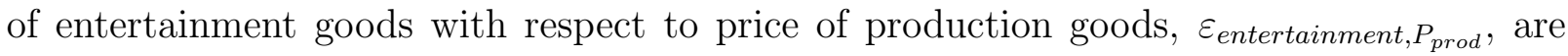
not identified in equation (B.2). The same problem occurs with own-price elasticity of entertainment goods, $\varepsilon_{\text {entertainment, } P_{e n t}}$, and the price elasticity of production goods with respect to price of entertainment goods, $\varepsilon_{\text {production, } P_{\text {ent }}}$, as shown in equation (B.3). 


$$
\begin{gathered}
{\left[\varepsilon_{\text {production }, P_{\text {prod }}}-\varepsilon_{\text {entertainment }, P_{\text {prod }}}\right]=\alpha_{2} \frac{P_{\text {ent }} Q_{\text {ent }}}{Q_{\text {prod }}}-1} \\
{\left[\varepsilon_{\text {production }, P_{\text {ent }}}-\varepsilon_{\text {entertainment }, P_{\text {ent }}} \frac{Q_{\text {prod }}}{P_{\text {ent }} Q_{\text {ent }}}\right]=\alpha_{3} \frac{P_{\text {ent }}}{P_{\text {prod }}}+\frac{Q_{\text {prod }}}{P_{\text {ent }} Q_{\text {ent }}}}
\end{gathered}
$$

Equation (B.4) is derived by differentiating the estimation equation with respect to the price of electricity. The price elasticity of production and entertainment goods with respect the price of electricity is not identified either. However, assuming that both goods are complements to electricity, since their services are only provided if electricity is available, it is possible to determine which good is more elastic depending on the coefficient of price of electricity, $\alpha_{4}$.

$$
\left[\varepsilon_{\text {production, } P_{\text {elect }}}-\varepsilon_{\text {entertainment }, P_{\text {elect }}}\right]=\alpha_{4} \frac{P_{\text {elect }}}{\text { share }_{p / e}}
$$

Regarding the income elasticity of production and entertainment goods, equation (B.5), the identification of which good is more income elastic depends on the coefficient of per capita monthly income, $\alpha_{5}$, as well as, on assumptions on the inferiority and normality of these goods.

$$
\left[\varepsilon_{\text {production }, M}-\varepsilon_{\text {entertainment }, M}\right]=\alpha_{5} \frac{M}{\text { share }_{p / e}}
$$

The expression for price and income elasticities when the dependent variable is the quantity ratio of production to entertainment goods, own $n_{p}$ are very similar to the set of equations discussed above for the dependent variable share s $_{e}$. The difference appears in equations (B.7) and (B.8), which measure the effects of the prices of production and 
entertainment goods. These differences are the results of the absence of prices of these goods in the quantity ratio. For the other equations, everything else is the same except for the share $_{p / e}$ being replaced by own $n_{p / e}$, and all the identification problems discussed above hold.

$$
\varepsilon_{\text {production }, P_{\text {maids }}}=\alpha_{1} P_{\text {maid }} \frac{Q_{\text {ent }}}{Q_{\text {prod }}}
$$

$$
\left[\varepsilon_{\text {production }, P_{\text {prod }}}-\varepsilon_{\text {entertainment }, P_{\text {prod }}}\right]=\alpha_{2} P_{\text {prod }} \frac{Q_{\text {ent }}}{Q_{\text {prod }}}
$$

$$
\left[\varepsilon_{\text {production, } P_{\text {ent }}}-\varepsilon_{\text {entertainment }, P_{\text {ent }}}\right]=\alpha_{3} P_{\text {ent }} \frac{Q_{\text {ent }}}{Q_{\text {prod }}}
$$

$$
\left[\varepsilon_{\text {production }, P_{\text {elect }}}-\varepsilon_{\text {entertainment }, P_{\text {elect }}}\right]=\alpha_{4} P_{\text {elect }} \frac{Q_{\text {ent }}}{Q_{\text {prod }}}
$$

$$
\left[\varepsilon_{\text {production }, M}-\varepsilon_{\text {entertainment }, M}\right]=\alpha_{5} M \frac{Q_{\text {ent }}}{Q_{\text {prod }}}
$$

